\title{
PENGEMBANGAN MEDIA PMBELAJARAN SMART SNAKE AND LADDER GAME PADA MATERI BANGUN RUANG SISI DATAR KELAS VIII
}

\author{
Vella Oktavia Rahejeng Pitaloka Rahman ${ }^{1}$ \\ ${ }^{I}$ MTs Al-Faqihiyah Pasuruan \\ E-mail: ${ }^{\text {vellaoctavia@gmail.com }}$
}

\begin{abstract}
Abstrak
Pengembangan ini bertujuan untuk mendeskripsikan proses pengembangan smart snake and ladder game pada materi bangun ruang sisi datar kelas VIII. Serta melakukan validasi dan uji coba media smart snake and ladder game pada materi bangun ruang sisi datar kelas VIII.Dalam pengembangan smart snake and ladder game pada materi bangun ruang sisi datar kelas VIII ini divalidasi oleh tiga validator yang meliputi satu ahli materi memperoleh skor 3,36 satu ahli desain dan media memperoleh skor 3,40 dan praktisi memperoleh skor 3,39 Sehingga dapat diperoleh rata-rata skor dari ketiga validator adalah 3,38, yang artinya media pembelajaran matematika smart snake and ladder game pada materi bangun ruang sisi datar kelas VIII adalah valid. Sedangkan pada validasi user dalam kelompok kecil memperoleh ratarata skor sebesar 3,33, yang artinya media pembelajaran matematika smart snake and ladder game pada materi bangun ruang sisi datar kelas VIII adalah valid.
\end{abstract}

Kata kunci: pengembangan, smart, game, bangun ruang

\section{PENDAHULUAN}

Pendidikan merupakan salah satu unsur penting dalam kehidupan, oleh karena itu perbaikan pada sistem pendidikan sangat penting untuk dilakukan. Karena pendidikan merupakan proses mencesdaskan kehidupan bangsa. Seiring perkembangan zaman, pendidikan sangat memerlukan inovasi dalam mencerdaskan suatu bangsa. Maka dari itu diperlukan paradigma-paradigma baru dalam proses pembelajaran, salah satu bidang ilmu pendidikan adalah matematika. Di dalam kehidupan sehari-hari matematika memiliki kegunaan yang nyata dan erat hubungannya denga ilmu-ilmu lain.

Pada umumnya pembelajaran matematika di Indonesia masih jauh dari kata memuaskan, bahkan kadang-kadang boleh dikatakan masih mengecewakan. Meskipun banyak dilakukan perbaikan dalam meningkatkan pembelajaran matematika, tetapi pada kenyataannya belum menunjukkan kemajuan yang berarti. Kebanyakan siswa menganggap bahwa matematika merupakan pelajaran yang sulit, sehingga tidak heran jika banyak siswa yang tidak suka atau bahkan takut ketika harus mempelajari atau menghadapi pembelajaran matematika. Karena anggapan ini, pembelajaran matematika menjadi rendah. Selain rasa takut pada kenyataannya pada pembelajaran matematika masih banyak guru yang menggunakan media yang monoton dan kurang menarik.

Kurangnya kreativitas dan inovasi guru dapat mempengaruhi proses belajar mengajar di kelas. Banyak guru di MTs. Al-Faqihiyah yang masih menggunakan media secara manual. Para guru sering kali tidak memanfaatkan perkembangan informasi dan teknologi pada zaman sekarang ini. Perkembangan informasi dan teknologi ikut serta dalam mendorong perkembangan dunia pendidikan. Sekarang, para guru dituntut untuk menguasai peralatan teknologi untuk menunjang proses belajar. Karena, perkembangan informasi dan teknologi sekarang ini dapat membantu para guru untuk komunikasi dalam proses belajar mengajar. Dalam proses belajar mengajar yang 
memanfaatkan perkembangan teknologi, guru dapat menggunakan atau membuat salah satu media permainan yang berbasis Informasi dan Teknologi (IT).

Menurut Hamalik (dalam Arsyad, 2011:2), guru harus memiliki pengetahuan dan pemahaman yang cukup tentang media pembelajaran, yang meliputi: media pembelajaran sebagai alat komunikasi guna lebih mengefektifkan proses belajar mengajar, fungsi media dalam rangka mencapai tujuan pendidikan; seluk beluk proses belajar yang menarik menggunkan media pembelajaran, hubungan antara metode mengajar dan media pendidikan, pemilian, dan pengunaan media pendidikan, berbagai jenis alat dan teknik media pendidikan, media pendidikan dalam setiap mata pelajaran, dan usaha inovasi dalam media pendidikan.

AECT (Association of Education and Communication Technology) (dalam Arsyad, 2013:3), memberi batasan tentang media sebagai segala bentuk dan saluran yang menggunakan untuk menyampaikan pesan atau informasi. Heinich dkk (dalam Arsyad, 2013:3), mengemukakan apabila media itu membawa pesan-pesan atau informasi yang bertujuan instruksional atau mengandung maksud-maksud pengajaran maka media itu disebut media pembelajaran. Sementara Gagne dan Briggs (dalam Arsyad, 2011:4), secara implisit mengatakan bahwa media pembelajaran meliputi alat secara fisik digunakan untuk menyampaikan isi materi pengajaran, yang terdiri dari antara lain buku, tape recorder, kaset, video kamera, video recorder, flim, slide (gambar bingkai), foto, gambar, grafik, televisi, dan komputer.

Penggunaan media pembelajaran dalam proses pembelajaran mengajar dapat membangkitkan keinginan dan minat, membangkitkan motivasi dan rangsangan kegiatan belajar, dan bahkan membawa pengaruh-pengaruh psikologis terhadap siswa. Penggunaan media pembelajaran pada tahap orientasi pembelajaran akan sangat membantu keefektifan proses pembealajaran dan penyampaian pesan dan isi pembelajaran pada saat itu. Media pembelajaran yang digunakan oleh para guru masih monoton, mereka banyak yang hanya menggunakan peralatan-peralatan manual seperti kertas dan lain-lain. Kurangnya kretivitas dan inovasi guru dapat mengurangi minat dan motivasi belajar peserta didik. Oleh karena itu, sangat dibutuhkan adanya media yang dapat menarik minat dan motivasi belajar peserta didik, salah satunya menggunakan media permainan.

Permainan adalah setiap konteks atara pemain yang interaksi satu sama lain dengan mengikuti atura-aturan tertentu untuk mencapai tujuan-tujuan tertentu pula (Rahmawati, 2009). Permainan dapat menjadi sumber belajar atau media belajar apabila permainan tersebut bertujuan untuk mencapai tujuan pendidikan atau pembelajaran. Permainan dengan tujuan spesifik sebagai alat pendidikan, untuk belajar mengenal warna, mengenal huruf dan angka, sampai belajar bahasa asing. Dengan perkembang teknologi dan zaman maka permainan dapat berbentuk atau berbasis multimedia interaktif.

Menurut Munir (2015:110), multimedia merupakan perpaduan antara berbagai media (format file) yang berupa teks, gambar (vector atau bitmap), grafik, sound, animasi, video, interaksi, yang dikemas, menjadi file digital (komputerisasi), digunakan untuk menyampaikan pesan kepada publik. Sedangkan interaktif adalah terkait dengan komunikasi dua arah atau lebih komponenkomponen. Berdasarkan pengertian multimedia dan interaktif, maka multimedia interaktif adalah suatu tampilan multimedia yang dirancang oleh designer agar tampilannya memenuhi fungsi menginformasikan pesan dan memilki interaktifitas kepada penggunanya (user).

Berdasarkan hasil pengamatan di MTs. Al-Faqihiyah, proses belajar matematika masih terkesan kurang menarik. Banyak peserta didik yang menginginkan proses pembelajaran yang menarik dan bervariasi. Sesuai kemajuan zaman dan perkembangan teknologi banyak peserta didik yang menyukai bermain dari pada belajar. Oleh karena itu pengembang ingin menarik minat dan motivasi belajar peserta didik dengan mengembangkan media yang diberi nama "smart snake and ladder game" yang berbasis multimedia interaktif.

Berdasarkan uraian di atas penulis tertatik untuk mengembangkan media pembelajaran smart snake and ladder game berbasis multimedia interaktif khusus pada materi bangun ruang sisi datar. 
Penelitian ini diberi judul "Pengembangkan media pembelajaran smart snake and ladder game berbasis multimedia interaktif materi bangun ruang sisi datar kelas VIII".

\section{METODE}

Pengembangan Media Pmbelajaran Smart Snake and Ladder Game Pada Materi Bangun Ruang Sisi Datar Kelas VIII ini dikembangkan dengan model pengembangan 4-D yang diadaptasi dari Thiagarajan (dalam Abidin dkk, 2014: 496). Model ini terdiri atas empat tahap utama yaitu: (1) Define (Pendefinisian/Kajian Awal), (2) Design (Perancangan), (3) Develop (Pengembangan), dan (4) Disseminate (Penyebaran). Adapun alasan pemilihan model pengembangan 4-D adalah karena model ini disusun secara terprogram yang disertai dengan urutan kegiatan yang sistematis, bersifat praktis dan mudah untuk digunakan.

Jenis data dalam pengembangan ini terdiri dari dua macam yaitu data kualitatif yakni data yang diperoleh dari komentar, kritik, dan saran pada lembar validasi data, serta data kuantitatif yakni skor penilaian yang ditulis pada angket yang mengenai penilaian terhadap produk matematika yang dikembangkan. Teknik analisis data disesuaikan dengan jenis data yang ada. Data kuantitatif diperoleh dari perhitungan skor pada angket, sedangkan data kualitatif berupa komentar, kritik, dan saran yang langsung dituliskan oleh ahli materi, ahli desain dan media, praktisi, dan user di lembar validasi kritik dan saran yang telah disediakan.

Lokasi yang digunakan dalam pengembangan ini yaitu MTs Al-Faqihiyah Pasuruan, pengembangan ini melibatkan 2 dosen pendidikan matematika, 1 guru matematika, dan 44 siswa dari MTs Al-Faqihiyah Pasuruan.

Prosedur pengembangan Media Pmbelajaran Smart Snake and Ladder Game Pada Materi Bangun Ruang Sisi Datar Kelas VIII berdasarkan model pengembangan 4-D adalah sebagai berikut. Pertama, tahap define atau pendefinisian, tahap ini terdiri dari tiga langkah pokok yaitu, (1) analisis ujung depan, (2) Analisis Materi, (3) analisis tugas.

Kedua, tahap design atau perancangan, tahap ini meliputi tiga langkah yaitu, (1) penyusunan flowchart, storyboard dan penyusunan materi bangun ruang sisi datar , (2) pemprograma media (3) penyusunan instrument penelitian.

Ketiga, tahap develop atau pengembangan, tahap ini terdiri dari tiga langkah yaitu, (1) validasi perangkat oleh para ahli dan praktisi diikuti dengan revisi, (2) simulasi yaitu kegiatan mengoperasikan media pembelajaran (3) uji coba terbatas dengan siswa yang sebenarnya.

Keempat, tahap disseminate atau penyebaran, tahap ini merupakan tahap penggunaan perangkat yang telah dikembangkan pada skala yang lebih luas misalnya di kelas lain, di sekolah lain, maupun oleh guru yang lain.

\section{HASIL}

\section{Pengembangan Produk}

Hasil dari pengembangan ini berupa media pmbelajaran smart snake and ladder game pada materi bangun ruang sisi datar kelas VIII. Dari analisis kebutuhan guru dan siswa terkait dengan media smart snake and ladder game diperoleh hasil bahwa $100 \%$ guru setuju dengan adanya smart snake and ladder game guna mendukung dan mempermudah menjelaskan materi selama proses pembelajaran, $84 \%$ siswa setuju dengan adanya smart snake and ladder game.

Media pembelajaran smart snake and ladder game pada materi bangun ruang sisi datar kelas VIII ini secara umum terdiri dari beberapa bagian. Berikut tampilan bagian media pmbelajaran smart snake and ladder game pada materi bangun ruang sisi datar kelas VIII sebagai berikut. 


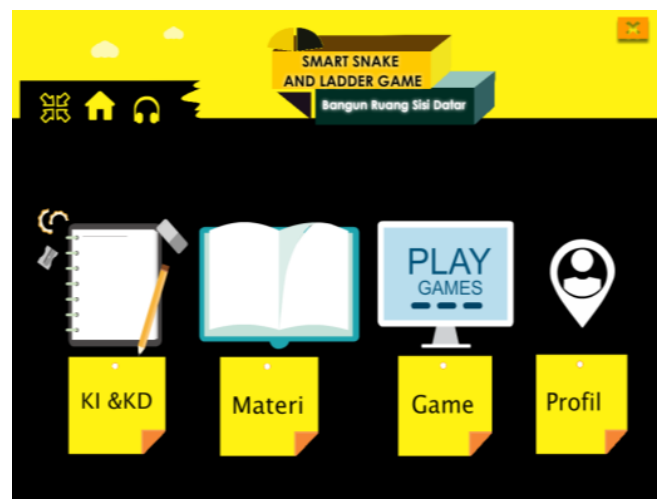

Gambar 1. Tampilan Halaman Utama

Bagian Pada halaman utama terdiri dari menu-menu materi, yang terdiri dari KI dan KD, materi, Game, Profil.

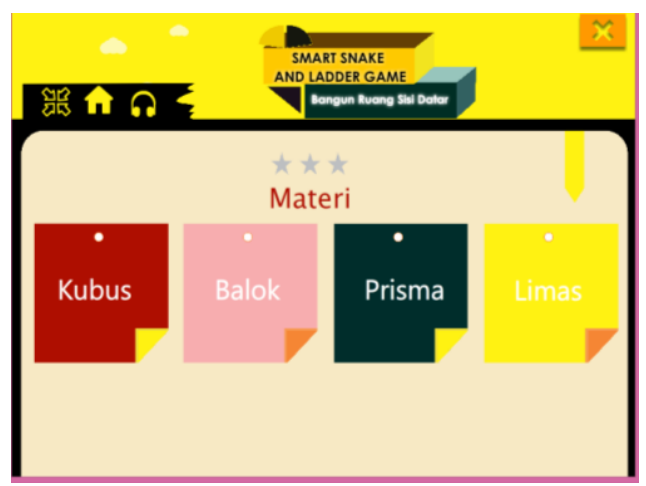

Gambar 2. Tampilan Bagian isi

Pada bagian isi terdiri dari kubus, balok, prisma, dan limas. contoh soal beserta pembahasan, latihan soal, uji kompetensi, dan rangkuman materi.

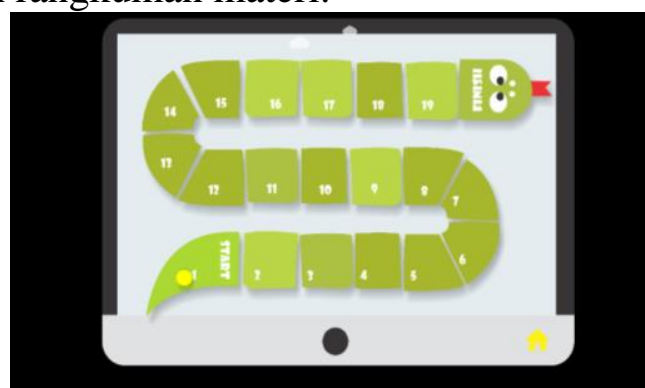

Gambar 3. Tampilan Smart Snake and Ladder Game

Bagian tampilan smart snake and ladder game terdapat bidak-bidak permainan yang didalam bidak terdapat soal-soal yang memuat bangun ruang sisi datar kelas VIII.

\section{Telaah Ahli}

Pada uji validasi smart snake and ladder game, terdapat tiga validator yaitu validator ahli materi, validator ahli desain dan media, dan validator praktisi. Berikut adalah hasil validasi ahli materi, ahli desain dan media, dan praktisi. 
Tabel 1 Analisis Data Validasi oleh Ahli Materi

\begin{tabular}{llccccc}
\hline No. & Aspek & $\sum \boldsymbol{X}_{\boldsymbol{i}}$ & $\boldsymbol{n}_{\mathbf{1}}$ & $\frac{\sum \boldsymbol{X}_{\boldsymbol{i}}}{\boldsymbol{n}_{\mathbf{1}}}$ & $\mathbf{S}$ & Katagori \\
\hline 1. & Isi dan Tujuan & 24 & 7 & 3,42 & 3,42 & Valid \\
\hline 2 & Teknis & 33 & 9 & 3,66 & 3,66 & Valid \\
\hline 3 & Pembelajaran & 9 & 3 & 3,00 & 3,00 & \multirow{2}{*}{ Valid } \\
\hline & $\sum \boldsymbol{S}_{\boldsymbol{i}}$ & & & $\mathbf{1 0 , 0 8}$ & \\
\hline & $\boldsymbol{K}=\frac{\sum \boldsymbol{S}_{\boldsymbol{i}}}{\boldsymbol{n}_{\mathbf{2}}}$ & & & $\mathbf{3 , 3 6}$ & \multirow{2}{*}{ Valid } \\
\hline
\end{tabular}

Tabel 2 Analisis Data Validasi oleh Ahli Media

\begin{tabular}{|c|c|c|c|c|c|c|c|}
\hline No. & & Aspek & $\sum x_{i}$ & $n_{1}$ & $\frac{\sum X_{i}}{n_{1}}$ & $\mathbf{S}$ & Katagori \\
\hline & Isi & & 32 & 9 & 3,55 & 3,55 & valid \\
\hline 2. & Tampilan & & 26 & 8 & 3,25 & 3,25 & valid \\
\hline & & $\sum s_{i}$ & & & & 6,80 & \\
\hline & & $K=\frac{\sum S_{i}}{n_{2}}$ & & & & 3,40 & Valid \\
\hline
\end{tabular}

Tabel 3. Analisis Data Validasi oleh Praktisi

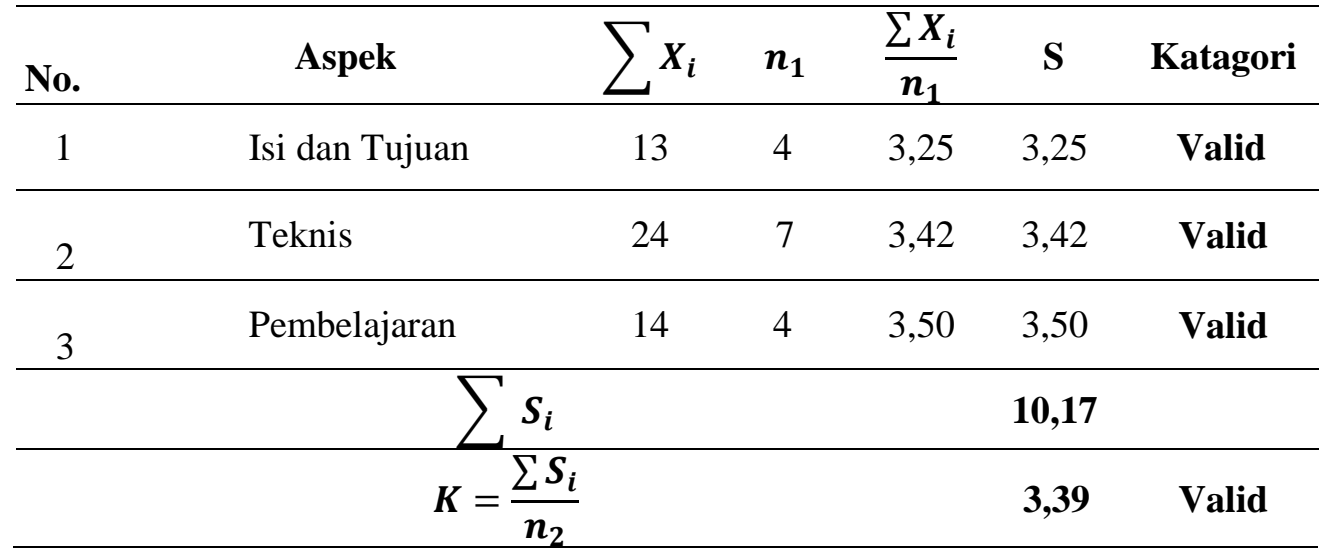

Berdasarkan hasil analisis data validasi ahli dan praktisi, diperoleh data sebagai berikut: (1) rata-rata total dari aspek yang dinilai oleh validator ahli materi adalah 3,36 (valid), (2) rata-rata total dari aspek yang dinilai oleh validator ahli desain dna media adalah 3,40 (valid), dan (3) rata-rata total dari aspek yang dinilai oleh validator praktisi adalah 3,39 (valid).

Setelah smart snake and ladder game melalui uji validasi, selanjutnya diujicobakan kepada siswa dalam kelompok kecil (user), yaitu 6 siswa MTs Al-Faqihiyah Pasuruan.

Tabel 4. Analisis Data Kelompok Uji Pengguna

\begin{tabular}{llcc}
\hline No. & Kelompok Uji Pengguna & K & Keterangan \\
\hline 1. & $\begin{array}{l}\text { Uji pengguna peserta didik berkemampuan } \\
\text { matematika tinggi }\end{array}$ & $\mathbf{3 , 3 4}$ & Valid \\
\hline 2. $\begin{array}{l}\text { Uji pengguna peserta didik berkemampuan } \\
\text { matematika sedang }\end{array}$ & $\mathbf{3 , 5 2}$ & Valid \\
\hline 3. $\begin{array}{l}\text { Uji pengguna peserta didik berkemampuan } \\
\text { matematika kurang }\end{array}$ & $\mathbf{3 , 1 5}$ & Valid
\end{tabular}




\begin{tabular}{ccc}
$\sum K_{i}$ & 10,01 & \\
\hline Rata-rata total $=\frac{\sum K_{i}}{N}$ & 3,33 & Valid \\
\hline
\end{tabular}

Berdasarkan data hasil ujicoba user, diperoleh skor rata-rata penilaian 3,33 yang berarti smart snake and ladder game dapat dikategorikan valid. Dengan demikian smart snake and ladder game layak digunakan dalam pembelajaran pada kelompok yang lebih luas.

\section{Revisi Produk}

Untuk mencapai produk yang mendekati sempurna dan memenuhi target ketepatan, kelayakan, dan kegunaan produk, maka media pembelajaran smart snake and ladder game pada materi bangun ruang sisi datar kelas ini melawati revisi sampai pada hasil akhir yang yang siap digunakan. Revisi yang dilakukan adalah sebagai berikut: background yang lebih simpel.

\section{PEMBAHASAN}

Menurut Borg dan Gall (dalam Setyosari, 2015:276), pengertian pengembangan adalah suatu proses yang dipakai untuk mengembangkan dan memvalidasi produk pendidikan. Dalam pengembangan ini, pengembang menghasilkan media pembelajaran smart snake and ladder game pada materi bangun ruang sisi datar kelas VIII.

Menurut Munir (2015:110), multimedia merupakan perpaduan antara berbagai media (format file) yang berupa teks, gambar (vector atau bitmap), grafik, sound, animasi, video, interaksi, yang dikemas, menjadi file digital (komputerisasi), digunakan untuk menyampaikan pesan kepada publik. Sedangan interaktif adalah terkait dengan komunikasi dua arah atau lebih komponenkomponen. Berdasarkan pengertian multimedia dan interaktif, maka multimedia intraktif adalah suatu tampilan multimedia yang dirancang oleh designer agar tampilannya memenuhi fungsi menginformasikan pesan dan memilki interaktifitas kepada penggunanya (user).

Pengembangan smart snake and ladder game berbasisi multimedia interaktif memberi kesempatan siswa belajar mandiri dan meningkatkan motivasi belajar. Smart snake and ladder game berbasisi multimedia interaktif berisi bangun ruang sisi datar (kubus, balok, limas, prisma).

Pengembangan ini menggunakan tahapan-tahapan model pengembangan 4-D seperti yang disarankan Thigarajan (dalam Trianto, 2017:93) yang terdiri dari empat tahapan yaitu tahap define (pendefinisian), design (perancangan), develop (pengembangan), dan disseminate (penyebaran).

Validasi produk smart snake and ladder game pada materi bangun ruang sisi datar kelas VIII dilakukan oleh tiga validator yaitu validator ahli materi, ahli desain dan praktisi, serta di uji cobakan kepada user dalam kelompok kecil yang terdiri dari 6 peserta didik. Pedoman untuk menginterpretasikan hasil analisis data yang diadaptasi dari Widoyoko (2012:110). Hasil uji coba user dalam kelompok kecil diperoleh rata-rata skor sebesar 3,33 yang artinya media pembelajaran matematika smart snake and ladder game pada materi bangun ruang sisi datar kelas VIII adalah valid. Sedangkan penilaian dari validasi ahli media diperoleh skor 3,40 sehingga dapat dinyatakan valid, sedangkan penilaian dari validasi ahli materi diperoleh skor 3,36 dan juga dinyatakan valid, dan untuk penilaian dari hasil praktisi dengan skor 3,39 juga dapat dikatakan valid. Sehingga dapat diperoleh rata-rata skor dari ketiga validator adalah 3,38, yang artinya media pembelajaran matematika smart snake and ladder game pada materi bangun ruang sisi datar kelas VIII adalah valid.

\section{SIMPULAN DAN SARAN}

Produk dalam pengembangan ini adalah media pembelajaran matematika smart snake and ladder game pada materi bangun ruang sisi datar kelas VIII. Adapun model pengembangan yang digunakan yaitu model pengembangan 4-D yang terdiri dari tahap define, design, develop, dan disseminate. 
Media pembelajaran matematika smart snake and ladder game pada materi bangun ruang sisi datar kelas VIII ini telah divalidasi dan layak digunakan sebagai media dalam proses pembelajaran matematika khusus siswa kelas VIII MTs Al-Faqihiyah pada materi bangun ruang sisi datar.

Dalam pemanfaatan media pembelajaran matematika smart snake and ladder game ini diharapkan guru maupun siswa dapat memanfaatkannya dengan baik.

\section{DAFTAR RUJUKAN}

Abidin, Z., \& Walida, S. E. (2014). The Model Of Mathematics E-Portofolio Assesment For Senior High School. ARPN Journal of Science and Technology, 4(10) 596-600.

Arsyad, A. (2011). Media Pembelajaran. Jakarta: PT Raja Grafindo.

Munir. (2013). Multimedia; Konsep dan Aplikasi Dalam Pendidikan. Bandung: Alfabeta.

Setyosari, P. (2015). Metode Penelitian Pendidikan \& Pengembangan. Jakarta: Kencana Prenada Media Group.

Trianto. (2017). Model Pembelajaran Terpadu. Jakarta: Bumi Aksara

Widoyoko, E. P. (2012). Teknik Penyusunan Instrumen Penelitian. Yogyakarta: Pustaka Pelajar. 